\title{
Credit Concession through credit scoring: Analysis and application proposal
}

\author{
Oriol Amat ${ }^{1}$ (D), Raffaele Manini ${ }^{1}$ (D), Marcos Antón Renart ${ }^{2}$ (D) \\ ${ }^{1}$ Universitat Pompeu Fabra (Spain) \\ ${ }^{2}$ Universidad de Murcia (Spain) \\ oriol.amat@upf.edu,raffaele.manini@,alum.upf.edu,_mantonn@um.es
}

Received October, 2016

Accepted November, 2016

\section{Abstract}

Purpose: The study herein develops and tests a credit scoring model which can help financial institutions in assessing credit requests.

Design/methodology: The empirical study has the objective of answering two questions: (1) Which ratios better discriminate the companies based on their being solvent or insolvent? and (2) What is the relative importance of these ratios? To do this, several statistical techniques with a multifactorial focus have been used (Multivariate Analysis of Variance, Linear Discriminant Analysis, Logit and Probit Models). Several samples of companies have been used in order to obtain and to test the model.

Findings: Through the application of several statistical techniques, the credit scoring model has been proved to be effective in discriminating between good and bad creditors.

Research limitations/implications: This study focuses on manufacturing, commercial and services companies of all sizes in Spain; Therefore, the conclusions may differ for other geographical locations. 
Practical implications: Because credit is one of the main drivers of growth, a solid credit scoring model can help financial institutions assessing to whom to grant credit and to whom deny it.

Social implications: Because of the growing importance of credit for our society and the fear of granting it due to the latest financial turmoil, a solid credit scoring model can strengthen the trust toward the financial institutions assessment's.

Originality/value: There is already a stream of literature related to credit scoring. However, this paper focuses on Spanish firms and proves the results of our model based on real data. The application of the model to detect the probability of default in loans is original.

Keywords: Credit scoring, Banking, Default

Jel Codes: M1

\section{Introduction}

Credit is as old as trade. However, the history of credit scoring is very short, just six decades old (Abdou \& Pointon, 2011). As a consequence of the exponential growth of the demand for credit, financial institutions have the need to develop automated risk evaluation systems (scoring) and they have to hire specialized consulting agencies to perform customers' evaluation and complex products evaluation (ratings) in order to rapidly evaluate the operations and to reduce the cost of analysis.

A credit scoring, is the process of collecting, analyzing and classifying different variables related to credit in order to asses credit decisions, Hand and Jacka, (1998, pp. 106) and Anderson (2007). This assessment is based on the comparison between the subject asking for credit and previous subjects who asked for credit. It is an automated system of assessment of the credit capacity of the subjects requesting credit operations which facilitate the concession or not of the credit requested with a high degree of accuracy, so to allow a reduction of default. Its form and application level varies substantially depending on the institution, Blöchlinger and Leippold (2006).

This is a relevant topic, especially after the last global financial crisis that shook the financial stabilities of many developed countries and even if many different factors generated the crisis, it gained relevance 
the importance of evaluating precisely the risks associated to credits of banks, Marshall, Tang and Milne (2010). The scoring is very generalized in relation to credit to allocate to specific customers, credit cards and mortgages. Based on Fair Isaac Company (2015) data, more than $75 \%$ of credit institutions use credit scoring to grant mortgages and more than $90 \%$ use it for credit cards.

In this way, the precise evaluation of the probability of loans default can at least help banks to rank their customers and improve the efficiency of the process related to credit concession. Moreover, a little improvement in the forecasting of the probability of default can bring substantial benefits to the money lender (Schreiner, 2002; Schreiner, 2004; De Young, Glennon \& Nigro, 2008).

To summarize, the purpose of credit scoring is nothing else but classifying credit applicants in two types: those with good credit, and consequently, higher probability to pay back their financial obligation, and those with bad credit with higher probability of defaulting (Wang, Hao, Ma \& Jiang, 2011). According to these authors, the main objective of their research regarding credit scoring was to determine the variables that have significant influence in the probability of default (Viganó, 1993; Thomas, 2000; Dinh \& Kleimeier, 2007; Caudill, Gropper \& Hartarska, 2012).

This paper has the objective of identifying which ratios better discriminate the companies either as solvent or insolvent and to know what is the relative importance of these ratios.

The rest of the work is organized as follow. In the second part, previous works related to credit scoring are described. In the third part, the methodology, techniques of analysis and variables are exposed. In the fourth part, the empirical results are analyzed. Finally, in the conclusive part the main results are addressed.

\section{Literature review}

The main idea behind the concept of credit evaluation is to compare the profile of a customer with the profile of previous customers who received credit in the past and were able to pay it back. Therefore, if a customer has a profile similar to the one of a previous customer who obtained credit and was able to be solvent, then the financial institution would grant credit (Abdou \& Pointon, 2011). In order to do so, there is the possibility of applying two techniques: "Loans officer's subjective assessment and credit scoring" (Crook, 1996). When talking about subjective assessment, it usually means the creditor's judgmental assessment. The creditor will have to go through a process which will take into account 
several factors, both quantitative and qualitative about the individual requesting credit, and it will be driven mainly by the creditor's experience. The advantage of this approach is that it takes into account also qualitative variables, even behavioral ones which are very difficult to include in a statistical model. On the other hand, a credit scoring model is a more objective and statistically accurate measure to make decisions which has been proven to be the most effective tool credit institutions have in order to make credit related decisions. A statistical approach is also a way to avoid misalignment of information similar to the audit expectation gap whose causes are explained in Saladrigues and Grañó (2014). To obtain a scoring, several statistical techniques are used, starting from the information regarding the applicant (income level, employment history, properties...) and the characteristics of particular loans based on previous operations (payments met, defaults...) to forecast possible future developments. Based on the level of risk the bank wants to take on, the loan is granted or not; and based on the punctuality of the payments, a tariff to pay or a guarantee is established in order to make the operation even safer. The Scoring can be applied to both companies and individuals and it is applied in different phases, Amat, Pujadas and Lloret (2012):

- Customer identification phase. In this phase, financial entities can identify those customers having an appropriate profile to receive the loan (Arimany \&Viladecans, 2015).

- Phase of initial study of the operation to decide whether to accept or not (acceptance scoring).

- Once the credit has been granted, there is a phase of post monitoring (Behavioral scoring). During this phase, the scoring is applied to the customers who obtained the loans and it is useful to assess if it is worth to keep the customer or not, if it is better to increase or reduce the limits allowed, to identify too risky customers before it is too late and establish interests and commissions for the renewals.

- Phase of default. In case the customer defaults, the scoring helps to evaluate the level of possible losses and the most appropriate actions to take in order to recover the defaulted payment.

The first scoring for credit operations was designed in the USA for the FICO company (1958) and the first scoring for credit cards was designed for Montgomery Ward (1960) and for American Bank and Trust (1970). Today, most of the institutions have their own scoring system and there are also companies which fill report about their customers based on their scorings, such as Equifax, Experian, Transunion and Axesor. 
Other traditional models are the one from Altman (1968) who developed a popular model to forecast the probability of a company going bankrupt; the one from Argenti (1983) whose aim is to determine the probability of insolvency using variables related to management and control; the Credit - men model proposed by Wall (1928) has the aim to determine the position of a company with respect to other companies operating within the same sector; the Edminster (1972) is a more complex model than the Credit-men because it selects those companies which are similar in certain parameters, while it excludes those which do not meet those parameters; or the Conan and Holder (1979) model, developed in France through the use of discriminant analysis to determine the probability of a company to suspend its interest payments.

Without any doubt, until today, several types of credit scoring models have been developed and applied with success to support the approval of credit decisions, being one of the main objectives of the credit scoring system the classification of samples of similar groups. Generally the problems of the credit scoring appear in the classification based on statistical methods (Hsieh \& Hung, 2010).

Below, we show other previous works of international level and what techniques they applied to elaborate the models. In Spain, the appearance of these techniques of automated evaluation occurred around 1983 (Bonilla, Olmeda \& Puertas, 2003). The authors make a comparison between parametric models (discriminant analysis and Logit) and non-parametric models (trees, neural networks, algorithm C4.5...) to determine the concession of credit cards and they conclude that discriminant models resulted to be so powerful in predictive terms that non parametric models do not dominate systematically the parameters.

$\mathrm{Hu}$ and Ansell (2007) analyze for the retailing sector the usefulness of the models for credit risk evaluation. In this way, they compare four classical methodologies (Naïve Bayes, logistic regression, recursive partitioning and artificial neuronal networks) with the Sequential Minimal Optimization (SMO). They used a sample of 195 healthy companies and 51 taht went bankrupt from 1994 to 2002. The five methodologies behaved well in predicting bankruptcy, in particular, one year before the event took place; moreover, it contrasts to how it was possible to predict up to five years in advance the bankruptcy with a level of accuracy superior to $78 \%$ and how none of these methodologies resulted to be superior in this classification. This agrees with the previous results where it was posed as a sample how bankruptcy prediction models have a predictive capacity of up to five years before a company goes bankrupt and how it was expected that the closer we get to the bankruptcy event the higher the predictive ability, so the values of the ratios deteriorate at a higher intensity (Marín, Antón \& Mondragón, 2011). 
Bardos (1998) describes the tools used by the central bank of France during that time to assess credit concessions and he built a credit scoring system based on the linear discriminant analysis. Zhou, Lai and Yen (2009) compare the SVM (support vector machines) technique with six traditional methods, concluding that in general they obtain better results with the previously mentioned technique. On the other hand, Shu-Ting, Cheng and Hsieh (2009) confirm the excellent results obtained with SVM, but they affirm that through the CLC (Clustering-launched classification) they obtain better results. Paleologo, Elisseeff and Antonini (2010) compares the Subagging technique with other traditional techniques and concludes that with the latter he obtains better results.

In Argentina, Gutiérrez (2008) contrasts the similar results obtained among parametric techniques and uses, starting from the Central Debtors of the Financial system, a model of credit scoring through the Probit. He affirms that in the studies are usually applied parametric techniques instead of non-parametric ones because they are easier to use and to interpret than the more sophisticated non parametric one.

Jacobson and Roszbach (2003) give relevance to how, in general, credit scoring models have the inconvenience of the bias in the sample and they propose a method to give importance to the risk portfolio. They use a sample of 13.338 Swedish credit applicants to whom were granted or refused credit and they apply the Probit method. Their results stress that an efficient selection of the credit applicants can reduce the credit risk up to $80 \%$.

Also through the Probit, Marshall et al. (2010) explore a sample of the UK and the influence of the sample selection bias in the prediction of the probability of default. In Antón (2007) it is possible to see how influential are the different decisions that must be taken regarding the final model obtained (Variables and coefficients). For example, variations in the dependent variable, change in the sample of companies, change in the truncation point or the introduction of new variables in the model.

Ochoa, Galeano and Agudelo (2010) implement a methodology of discriminant analysis to build a scoring model to grant credit, through the statistical analysis of the qualitative and quantitative variables and for a facilitated database for a Colombian financial cooperative.

Wang, Ma, Huang and Xu (2012) analyze an Australian database and a German one in their study, as well as a Chinese database in Wang et al. (2011), and they recognize the wide use of discriminant techniques and logit in previous studies, and they advocate for the use of other techniques less used in the study of credit scoring such as the decision tree showing the usefulness of the latter. Other 
previous studies such as Zhou, Zhang and Jiang (2008), also utilize Australian and German data, and they approach credit scoring through the decision trees technique.

Another study using as data German applicants is the Kim and Son (2003) where, to strengthen the credit scoring management, they develop a credit scoring model through neuronal networks, dividing customers into four subgroups considering their current credit status and the results of the classification.

The study of Blanco, Pino-Mejías, Lara and Rayo (2013) uses neuronal networks as well. They develop several credit scoring models for the microfinance sector using several techniques such as the linear discriminant analysis and the logistic regression. They base their study on a sample of 5.500 loan applicants for a Peruvian microfinance institution, concluding that for the microfinance sector, the results coming from neuronal networks are better than those obtained with traditional techniques.

Rayo, Lara and Camino (2010) focus on microfinance institutions (IMFs) and design a credit scoring model for a Peruvian institution under supervision and specialized in microcredit through logistic regression analysis. In this sense, Van Gool, Verbeke, Sercu and Baesens (2012), analyze if microfinance institutions can benefit from credit scoring, confirming the absence of quantitative evidence for East Europe, central Asia and Africa. They develop and confirm the validity of the logistic regression models using data from Bosnia Herzegovina, getting to the conclusion that credit scoring is not able to completely replace the human factor in the process of granting credit and nonetheless is recommendable to introduce these models as tools to improve the process of credit in combination with the human factor.

With respect to the assessment of models, Dryver and Sukkasem (2009) focus on obtaining a better understanding of the existing different methodologies to validate the existing risk models used for credit scoring purposes. Other authors, such as Chuang and Lin (2009) brought up a model of resignation of credit scoring with the aim of improving the correctness of the model classification and to minimize the Type I error.

This report of previous studies is a sample of the diversity of studies related to credit scoring as well as its techniques and variables. A more detailed revision about previous studies can be found in Allen, De Long and Saunders (2004) or more recently in Abdou and Pointon (2011), who analyze 214 articles, books and thesis about statistical techniques and evaluation criteria in credit scoring, concluding, among other things, that it does not exist yet a technique that dominates the others. It also deserves special 
attention the study of Tascón and Castaño (2012), who realize a large revision of previous studies related to business bankruptcy, models and variables.

\section{Methodology}

This empirical study has the objective of identifying a function which discriminates the companies based on a higher or lower ability to meet their debt obligations. The companies with higher probability of meeting their obligations will be considered solvent whereas the ones with a lower probability of being able to meet their obligations will be considered insolvent. In this sense, we will try to answer the two following questions:

(1) Which ratios better discriminate the companies based on their being solvent or insolvent?

(2) What is the relative importance of these ratios?

To do that, several statistical techniques with a multifactorial focus have been used (Altman, 1968).

There are two reasons to explain the use of traditional statistical techniques rather than advanced statistical techniques such as neural networks, decision trees and genetic programming. First, there is the aim to follow (Altman, 1968) approach and second because traditional statistical techniques have been proven to have very good performance in the context of the paper. Even if some studies show that advanced statistical techniques have better performance when dealing with predictive abilities, other studies have shown that the predicting capabilities of both approaches were sufficiently similar to make it difficult to distinguish between them (Abdou \& Pointon, 2011).

\subsection{MANOVA}

Discriminant analysis is a simple parametric statistical technique which has been widely used in order to distinguish between bad credit customers and good credit customers, and even nowadays it keeps being considered one of the most appropriate techniques in order to make this kind of distinctions. For this reason, the first two techniques implemented in this paper belong to the family of discriminant analysis techniques and they are MANOVA and LDA. 
The Multivariate Analysis of Variance (MANOVA) has been used to detect those independent variables which have a greater discriminant power. In fact, it is a technique used to analyze the relationship between several response variables and common set of predictors at the same time. Let's assume a sample which includes the two different groups (solvent companies and insolvent companies) and where each observation contains different variables (ratios). The question is up to what point these groups are different with respect to these variables. This technique is particularly useful for the identification of the group of variables (ratios) which show a different performance between solvent and insolvent firms. The variables that show different profiles between the groups are of little utility to discriminate the companies. To sum up, the main objective of the MANOVA analysis is to determine if the response variables, in our case solvent and insolvent firms, are altered by the observer's manipulation of the independent variables which in this study is the possible inclusion or exclusion of certain accounting ratios.

\subsection{Linear Discriminant Analysis (LDA)}

The LDA is a technique which considers the complete profile of the companies and the interactions among the different characteristics. Moreover, the LDA is of great help when there is the need to classify only two groups of companies (in our case solvent and insolvent firms).

Similarly to Altman (1968), a series of ratios that previous literature identified as relevant to forecast insolvency were used. In our case 40 ratios have been used (see Table 1). Following Altman (1968) with the aim to find a final profile of the variables, the statistical significance of the alternative different functions that include the relative contribution of each variable (ratios) have been observed and it was also considered the accuracy of prediction of the different functions. 


\begin{tabular}{|c|c|}
\hline Financial Ratios & Economic Ratios \\
\hline 1. Current Assets / Current Liabilities & 22. COGS / Sales \\
\hline 2. (Receivables + Cash) / Current Liabilities & 23. Gross Margin / Sales \\
\hline 3. Cash/ Current Liabilities & 24. Employment Cost / Sales \\
\hline 4. (Current Assets - Current Liabilities)/ Current Liabilities & 25. Amortization / Sales \\
\hline 5. (Current Assets - Current liabilities)/Sales & 26. Losses/ Sales \\
\hline 6. Net Worth/ Total Assets & 27. Extraordinary Expenses/ Sales \\
\hline 7. Net Worth / Non-Current Assets & 28. Extraordinary Revenue/ Sales \\
\hline 8. Net Worth/ Total Liabilities & 29. Financial Expenses / Sales \\
\hline 9. Net Worth / Current Liabilities & 30. Financial Expenses / Loans \\
\hline 10. Current liabilities / Total Liabilities & 31. Sales $n /$ Sales $n-1$ \\
\hline 11. (Net profits + Depreciation + Amortization) $/$ Loans & 32. EBITDA/ Assets \\
\hline 12. (Net Profits + Depreciation + Amortization) $/$ Current liabilities & 33. EBITDA / Sales \\
\hline 13. EBITDA / Loans & 34. EBITDA/ Financial Expenses \\
\hline 14. EBITDA / Current Liabilities & 35. EBITDA / Net Profits \\
\hline 15. Sales / Assets & 36. Net profits / Assets \\
\hline 16. Sales / Non-Current Assets & 37. Net profits/ Sales \\
\hline 17. Sales / Current Assets & 38. Net profits / Net Worth \\
\hline 18. Sales/Inventory & 39. (Net profits - Retained earnings) / Net profits \\
\hline 19. COGS / Inventory & 40. (Net profits- Retained earnings) / Assets \\
\hline 20. (Receivables / Sales) x 365 & \\
\hline 21. (Suppliers /Purchases) $\times 365$ & \\
\hline
\end{tabular}

Table 1. Ratios used for the empirical study

The LDA tries to derive a linear combination of variables (ratios) that maximize the separations between the two groups. The discrimination is reached when meeting the vector that contains the discriminant weight for each one of the independent variables that better separate individual observations result from the two types of companies (solvent and insolvent).

With the aim of evaluating the accuracy of the discriminant model, several alternatives are proposed, which are shown in the classification matrix (see Table 2). A and D represent the correct classification and, on the contrary, B and C show classification errors:

- A is a company that knows to be insolvent and when the model is applied, the company results to be insolvent: CORRECT.

- B is a company known to be insolvent, but when the model is applied, the company results to be solvent: INCORRECT.

- $\mathrm{C}$ is a company known to be solvent, but when the model is applied, the company results to be insolvent: INCORRECT.

- $\mathrm{D}$ is a company known to be solvent and when the model is applied, the company results to be solvent: CORRECT. 


\begin{tabular}{|l|l|l|}
\cline { 2 - 3 } \multicolumn{1}{c|}{} & \multicolumn{2}{c|}{ Predicted Group } \\
\hline Actual Group & \multicolumn{1}{c|}{ Insolvent } & Solvent \\
\hline Insolvent & A & B \\
\hline Solvent & C & D \\
\hline
\end{tabular}

Table 2. Companies' classification matrix

The aim is to identify a model which afterwards can be applied to other companies to predict if those are solvent or insolvent

\subsection{Logit and Probit Models}

Logit and Probit models are conventional techniques used in credit scoring. These techniques find coefficient values such that it is the probability of a unit value of a dichotomous coefficient. Under a Probit model a combination of the independent variables is transformed into its cumulative probability value from a normal distribution. Therefore, they are models of binary election, which is a class of econometrics models where the "dependent" variable is qualitative assuming only two values $(0 / 1)$. Usually, 1 represent a success while 0 represents a failure. Grablowsky and Talley (1981, pp. 260), stated that, under Probit analysis, normal distributions of the "threshold values" are assumed, while multivariate normal distributions and equal variances are assumed under discriminant analysis.

In order to perform this study, we have used a sample of 80.000 Spanish companies that received a loan from a bank (for confidentiality reasons, the name of the bank is anonymous) in 2005 and 2006. Around $85 \%$ of the companies were successful in meeting their interest payments and principal payment at maturity during the following years. However, about 15\% of them defaulted their credit obligations. To be more specific, based on the Spanish regulation, a firm is considered defaulting their credit obligations when it either does not pay back the principal amount at maturity or, in case of long term loans, it does not meet at least three periodical interest payment. 


\section{Results}

Among all the possible MANOVA combinations the ones with a higher discriminant power were identified. This is a fundamental step for determining which are the accounting ratios that significantly differentiate a solvent firm from an insolvent one. According to our results

(1) Which ratios better discriminate the companies based on their being solvent or insolvent? We have calculated 40 of these companies' ratios (see Table 1). These 40 ratios have been identified in the literature review as ratios with more discriminant power. The four ratios in Table 3 are the ones with a higher power to discriminate between solvent and insolvent firms:

\begin{tabular}{|l|r|r|}
\hline Ratio & $\begin{array}{l}\text { Average of the ratio for } \\
\text { Insolvent companies }\end{array}$ & $\begin{array}{l}\text { Average of the ratio for } \\
\text { Solvent companies }\end{array}$ \\
\hline Current Assets (CA)/ Current Liabilities (CL) & $<1.2$ & $\geq 1.42$ \\
\hline Net worth(NW) / Assets (A) & $<0.3$ & $\geq 0.4$ \\
\hline Net profits (NP) / Assets (A) & $<0.01$ & $>0.05$ \\
\hline Net Profits (NP) / Net Worth (NW) & $<0.03$ & $>0.07$ \\
\hline
\end{tabular}

Table 3. Ratios with higher predictive power

Among the 40 ratios analyzed, these four are the ones which discriminate the most between solvent and insolvent firms.

(2) What is the relative importance of these ratios? The $\mathrm{Z}$ formula obtained is the one that best assess a company as insolvent when its value is less than zero and it assesses as solvent when the value is above zero.

$$
\mathrm{Z}=-3.9+1.28(\mathrm{CA} / \mathrm{CL})+6.1(\mathrm{NW} / \mathrm{A})+6.5(\mathrm{NP} / \mathrm{A})+4.8(\mathrm{NP} / \mathrm{NW})
$$

As a consequence, through the discriminant analysis we have identified an integrated function for several ratios that resulted useful to asses if a company can be classified as solvent or insolvent. When the value of the previous formula is above zero, it indicates that there is a high probability that the company is financially healthy whereas when the value is below zero, there is a high probability that the company has insolvency problems.

We have applied the formula to both the healthy firms and the firms with problems (see Table 4). As it is possible to verify, companies with problems obtain a negative $Z$ value, whereas the healthy companies obtain a value greater than zero. 


\begin{tabular}{|c|c|c|}
\hline & $\begin{array}{l}\text { Average of the ratios } \\
\text { Insolvent companies }\end{array}$ & $\begin{array}{l}\text { Average of the ratios } \\
\text { Solvent companies }\end{array}$ \\
\hline Current Assets/ Current Liabilities & 1.2 & 1.42 \\
\hline Net Worth / Assets & 0.3 & 0.4 \\
\hline Net Profit / Assets & 0.01 & 0.05 \\
\hline Net Profit / Net Worth & 0.03 & 0.07 \\
\hline $\begin{array}{l}Z \\
-3.9+1.28 \times 1+6.1 \times 2+6.5 \times 3+4.8 \times 4\end{array}$ & -0.325 & 1.0186 \\
\hline
\end{tabular}

Table 4. Application of the $\mathrm{Z}$ score to healthy companies and companies with problems

\section{Testing the model}

To test the usefulness of the model, we applied it to two different samples.

\subsection{First test of the model}

To test the usefulness of the model, we have analyzed a sample of 2,000 short term credits issued by the same bank at the end of 2008. Out of these 2,000 short term credits, 144 had problems of insolvency in the time span that goes from the date of issuance till the end of 2010. In Table 5 there is the application of the model to the described loans and the interpretation is as follows: a value of $\mathrm{Z}$ equal to 0.8 means that the bank granted a loan to 1,324 companies with a value of $Z$ equal to 0.8 or less. Of these loans, 4 resulted to be defaulting, meaning a $0.8 \%$ default rate. Given that the default rate of this list of loans was of $7.2 \%$, if the bank would have demanded a lower $\mathrm{Z}$ score from the companies, it could have reduced the default rate. For example, if the maximum default rate acceptable had been $1.8 \%$, it should not have been granted a loan to any company obtaining a $\mathrm{Z}$ score of -0.8 . This means that there would have been issued only 1,747 loans of the 2,000 authorized at the end, and 32 would end up as default loans. 


\begin{tabular}{|c|c|c|c|c|c|}
\hline $\mathrm{Z}$ value & Loans issued & $\begin{array}{l}\text { Sum of loans } \\
\text { issued }\end{array}$ & $\begin{array}{c}\text { Defaulting } \\
\text { loans }\end{array}$ & $\begin{array}{c}\text { Sum of } \\
\text { defaulting loans }\end{array}$ & $\begin{array}{l}\text { Percentage of } \\
\text { defaulting loans } \\
\text { over total loans } \\
\text { granted }\end{array}$ \\
\hline 3.4 & & 0 & & 0 & 0.0 \\
\hline 3.2 & & 0 & & 0 & 0.0 \\
\hline 3 & 18 & 18 & & 0 & 0.0 \\
\hline 2.8 & 53 & 71 & & 0 & 0.0 \\
\hline 2.6 & 78 & 149 & & 0 & 0.0 \\
\hline 2.4 & 74 & 223 & 1 & 1 & 0.4 \\
\hline 2.2 & 131 & 354 & & 1 & 0.3 \\
\hline 2 & 94 & 448 & & 1 & 0.2 \\
\hline 1.8 & 88 & 536 & & 1 & 0.2 \\
\hline 1.6 & 152 & 688 & & 1 & 0.1 \\
\hline 1.4 & 221 & 909 & 2 & 3 & 0.3 \\
\hline 1.2 & 181 & 1090 & & 3 & 0.3 \\
\hline 1 & 121 & 1211 & 1 & 4 & 0.3 \\
\hline 0.8 & 113 & 1324 & & 4 & 0.3 \\
\hline 0.6 & 96 & 1420 & 1 & 5 & 0.4 \\
\hline 0.4 & 74 & 1494 & 3 & 8 & 0.5 \\
\hline 0.2 & 51 & 1545 & 2 & 10 & 0.6 \\
\hline 0 & 64 & 1609 & 1 & 11 & 0.7 \\
\hline-0.2 & 41 & 1650 & 5 & 16 & 1.0 \\
\hline-0.4 & 34 & 1684 & 4 & 20 & 1.2 \\
\hline-0.6 & 35 & 1719 & 8 & 28 & 1.6 \\
\hline-0.8 & 28 & 1747 & 4 & 32 & 1.8 \\
\hline-1 & 29 & 1776 & 11 & 43 & 2.4 \\
\hline-1.2 & 31 & 1807 & 3 & 46 & 2.5 \\
\hline-1.4 & 28 & 1835 & 21 & 67 & 3.7 \\
\hline-1.6 & 34 & 1869 & 18 & 85 & 4.5 \\
\hline-1.8 & 46 & 1915 & 22 & 107 & 5.6 \\
\hline-2 & 13 & 1928 & 5 & 112 & 5.8 \\
\hline-2.2 & 39 & 1967 & 18 & 130 & 6.6 \\
\hline-2.4 & 25 & 1992 & 12 & 142 & 7.1 \\
\hline-2.6 & 8 & 2000 & 2 & 144 & 7.2 \\
\hline-2.8 & & 2000 & & 144 & 7.2 \\
\hline-2.8 & & 2000 & & 144 & 7.2 \\
\hline-3 & & 2000 & & 144 & 7.2 \\
\hline-3.2 & & 2000 & & 144 & 7.2 \\
\hline-3.4 & & 2000 & & 144 & 7.2 \\
\hline-3.6 & & 2000 & & 144 & 7.2 \\
\hline-3.8 & & 2000 & & 144 & 7.2 \\
\hline \multirow[t]{2}{*}{-4} & & 2000 & & 144 & 7.2 \\
\hline & 2000 & 2000 & 144 & 144 & 7.2 \\
\hline
\end{tabular}

Table 5. Application of the model to Spanish companies in a list of credit of a bank

This test proves that the $\mathrm{Z}$ score can be useful to reduce the default rate. Since it proves that there is a close relationship between the value of the $Z$ and the default rate, the value of the $Z$ for each company could be used to fix the interest rate considering the default risk. When the $\mathrm{Z}$ is lower the risk of default is higher so the bank should deny the loan or increase the interest rate. 


\subsection{Second test of the model}

Following is another example of use of this kind of scoring. In Table 6 the $\mathrm{Z}$ score has been applied to seven Spanish companies. We have used financial data from the year 2008 in order to check if the Z score can be a good predictor of future insolvency. As previously mentioned, a value above zero will be an indicator of a company financially healthy. In the example, a commercial TV station, a textile company, an airline company and a shopping center chain have a value greater than zero and they developed favorably during the years before the measurement. On the contrary, the companies having a negative $\mathrm{Z}$ value had less favorable circumstances. An airline company, a real estate company and a shopping center went under bankruptcy between 2009 and 2010.

\begin{tabular}{|c|c|c|c|c|c|c|c|}
\hline & $\begin{array}{l}\text { Commercial } \\
\text { TV } \\
2008\end{array}$ & $\begin{array}{l}\text { Textile } \\
\text { Company } \\
2008\end{array}$ & $\begin{array}{l}\text { Airline } \\
\text { Company } \\
2008\end{array}$ & $\begin{array}{l}\text { Shopping } \\
\text { Center Chain } \\
2008\end{array}$ & $\begin{array}{l}\text { Airline } \\
\text { Company } \\
2008\end{array}$ & \begin{tabular}{|l|} 
Real \\
Estate \\
Company \\
2008 \\
\end{tabular} & $\begin{array}{l}\text { Shopping } \\
\text { Center } \\
\text { Chain } \\
2008 \\
\end{array}$ \\
\hline $\begin{array}{l}\text { x1 } \\
\text { Current Assets/ } \\
\text { Currentliabilities }\end{array}$ & 2.54 & 1.21 & 2.11 & 0.78 & 1.5 & 1.9 & 0.57 \\
\hline $\begin{array}{l}\text { x2 } \\
\text { Net Worth/ } \\
\text { Assets }\end{array}$ & 0.64 & 0.59 & 0.45 & 0.56 & 0.1 & 0.004 & 0.31 \\
\hline $\begin{array}{l}\text { x3 } \\
\text { Net Profits / } \\
\text { Assets }\end{array}$ & 0.34 & 0.18 & 0.08 & 0.05 & 0.02 & 0.01 & -0.03 \\
\hline $\begin{array}{l}\text { x4 } \\
\text { Net profits / Net } \\
\text { Worth }\end{array}$ & 0.53 & 0.3 & 0.17 & 0.1 & 0.03 & 0.22 & -0.09 \\
\hline $\begin{array}{l}Z \\
-3.9+1.28 \times 1+6.1 \\
x 2+6.5 \times 3+4.8 \times 4\end{array}$ & 8.0092 & 3.8578 & 2.8818 & 1.3194 & -1.096 & -0.3226 & -1.9064 \\
\hline $\begin{array}{l}\text { Forecast for the } \\
\text { coming years }\end{array}$ & $\begin{array}{l}\text { Low } \\
\text { probability } \\
\text { of insolvency }\end{array}$ & $\begin{array}{l}\text { Low } \\
\text { probability } \\
\text { of } \\
\text { insolvency }\end{array}$ & $\begin{array}{l}\text { Low } \\
\text { probability } \\
\text { of } \\
\text { insolvency }\end{array}$ & $\begin{array}{l}\text { Low } \\
\text { probability of } \\
\text { insolvency }\end{array}$ & $\begin{array}{l}\text { High } \\
\text { probability } \\
\text { of } \\
\text { insolvency }\end{array}$ & $\begin{array}{l}\text { High } \\
\text { probability } \\
\text { of } \\
\text { insolvency }\end{array}$ & $\begin{array}{l}\text { High } \\
\text { probability } \\
\text { of } \\
\text { insolvency }\end{array}$ \\
\hline $\begin{array}{l}\text { Situation of the } \\
\text { company in } 2016\end{array}$ & $\begin{array}{l}\text { Operating } \\
\text { normally }\end{array}$ & $\begin{array}{l}\text { Operating } \\
\text { normally }\end{array}$ & $\begin{array}{l}\text { Operating } \\
\text { normally }\end{array}$ & $\begin{array}{l}\text { Operating } \\
\text { normally }\end{array}$ & $\begin{array}{l}\text { Bankruptcy } \\
\text { in } 2009\end{array}$ & $\begin{array}{l}\text { Bankruptcy } \\
\text { in } 2009\end{array}$ & $\begin{array}{l}\text { Bankruptcy } \\
\text { in } 2009\end{array}$ \\
\hline Conclusion & $\begin{array}{l}\text { The Z score } \\
\text { was a good } \\
\text { predictor }\end{array}$ & $\begin{array}{l}\text { The Z score } \\
\text { was a good } \\
\text { predictor }\end{array}$ & $\begin{array}{l}\text { The Z score } \\
\text { was a good } \\
\text { predictor }\end{array}$ & $\begin{array}{l}\text { The Z score } \\
\text { was a good } \\
\text { predictor }\end{array}$ & \begin{tabular}{|l} 
The Z \\
score was a \\
good \\
predictor
\end{tabular} & \begin{tabular}{|l} 
The Z \\
score was a \\
good \\
predictor
\end{tabular} & $\begin{array}{l}\text { The Z score } \\
\text { was a good } \\
\text { predictor }\end{array}$ \\
\hline
\end{tabular}

Note: The Z has been calculated using data of the year 2008

Table 6. Application of the Z score to seven Spanish firms 


\section{Conclusions}

Credit scoring is a tool eliciting a growing interest for financial institutions.

The literature also shows us the best variables for each particular case, but it still does not seem to exist unanimously a set of variables that should always be part of the model.

In this work, we have identified four ratios which have a high discriminant power in connection with solvency: Current Assets / Current Liabilities, Net Worth / Assets, Net Profit / Assets and Net Profit / Net Worth.

We have also developed a $\mathrm{Z}$ score model which can be used to predict solvency problems. The validity of the model has been tested over two different samples, showing a predictive power which can be useful to forecast defaults based on four ratios.

This work has several limitations. First, this kind of analysis has to be done with caution because in some industries the predictions might not be as accurate, especially in the cases where financial practices are very different (when there is rapid cash in from customers, or inventories tend to stay just for a short time in the company, as in supermarkets, for example). On the other hand, we agree with previous studies regarding the importance of the human factor in the process of granting credit. Without any doubt, it is recommendable to introduce these models as a tool to guide the decision making, but only as a complementary tool to the human factor and experience. Indeed, before applying any statistical model, a sound accounting analysis would be needed such as a detailed financial statement analysis of the company. It might seem evident, but several papers have shown the importance of financial statement analysis to assess companies' future performance such as Arimany and Viladecans (2015) who prove the importance of the statement of cash flow analysis to assess companies' performance.

Future extensions of this research line could include the development of $Z$ scores for special industries, for example, supermarkets. Moreover, it would be interesting to try to include behavioral variables within credit scoring models in order to merge the importance of human experience and statistical analysis. 


\section{References}

Abdou, H.A., \& Pointon, J. (2011). Credit Scoring, statistical techniques and evaluation criteria: A review of the literature. Intelligent System in Accounting, Finance and Management, 18, 59-88. https://doi.org/10.1002/isaf.325

Arimany, N., \& Viladecans, C. (2015). Analysis of the cash flow statement's usefulness: An empirical study. European Accounting and Management Review, 1, 75-100. https://doi.org/10.2139/ssrn.2737292

Allen, L., De Long, G., \& Saunders, A. (2004). Issues in credit risk modeling of retail markets. Journal of Banking and Finance, 28, 727-752. https://doi.org/10.1016/S0378-4266(03)00197-3

Altman, E. (1968). Financial ratios, discriminant analysis and the prediction of corporate Bankruptcy. Journal of Finance, 23(4)., 589-609. https://doi.org/10.1111/j.1540-6261.1968.tb00843.x

Amat, O., Pujadas, P., \& Lloret, P. (2012). Análisis de Operaciones de Crédito. Barcelona: Profit Editorial.

Anderson, R. (2007). The Credit Scoring Toolkit: Theory and practice for retail credit risk management and decision automation. New York: Oxford University Press.

Antón, M. (2007). Una propuesta alternativa en la valoración del riesgo de fracaso empresarial mediante la elaboración y aplicación a priori de modelos de predicción de alerta de crisis. Revista de Contabilidad y Tributación CEF, (288), 111-162.

Argenti, J. (1983). Predicting Corporate Failure, Institute of Chartered Accountants in English and Wales. Accountants Digest, 138, 1-25.

Bardos, M. (1998). Detecting the risk of company failure at Banque de France. Journal of Banking and Finance, 10-11, 1405-1419. https://doi.org/10.1016/S0378-4266(98)00062-4

Blanco, A., Pino-Mejías, R., Lara, J., \& Rayo, S. (2013). Credit scoring models for the microfinance industry using neural networks: Evidence from Peru. Expert Systems with Applications, 40, 356-364. https://doi.org/10.1016/j.eswa.2012.07.051

Blöchlinger, A., \& Leippold, M. (2006). Economic benefit of powerful credit scoring. Journal of Banking and Finance, 30, 851-873. https://doi.org/10.1016/j.jbankfin.2005.07.014

Bonilla, M, Olmeda, I., \& Puertas, R. (2003). Modelos paramétricos y no paramétricos en problemas de Credit Scoring. Revista Española de Financiación y Contabilidad, 118(32), 833-869. 
Caudill, S., Gropper, D., \& Hartarska, V. (2012). Microfinance institution costs: Effects of gender, subsidies and technology. Journal of Financial Economic Policy, 4(4), 292-304. https://doi.org/10.1108/17576381211279271

Chuang, C., \& Lin, R. (2009). Constructing a reassigning credit scoring model. Expert Systems with Applications, 36, 1685-1694. https://doi.org/10.1016/j.eswa.2007.11.067

Conan, J., \& Holder, M. (1979). Variables explicatives de performance et controle de gestion dans les P.M.I. Tesis, CERG, Université Paris Dauphine.

Crook, J.N. (1996). Credit scoring: An overview. Working paper series No. 96/13, British Association, Festival of Science. University of Birmingham, The University of Edinburgh.

De Young, R., Glennon, D., \& Nigro, P. (2008). Borrower-lender distance, credit scoring, and loan performance: Evidence from International-opaque small business borrowers. Journal of Financial Intermediation, 17, 113-143. https://doi.org/10.1016/j.jfi.2007.07.002

Dinh, T.H.T., \& Kleimeier, S. (2007). A credit scoring model for Vietnam's retail banking market. International Review of Financial Analysis, 16, 471-495. https://doi.org/10.1016/j.irfa.2007.06.001

Dryver, A.L., \& Sukkasem, J. (2009). Validating risk models with a focus on credit scoring models. Journal of Statistical Computation and Simulation, 2(79), 181-193. https://doi.org/10.1080/00949650701684678

Edminster, R.O. (1972). An Empirical Test of Financial Ratio Analysis for Small Business Failure Prediction. Journal of financial and Quantitative analysis, 2, 1477-1493. https://doi.org/10.2307/2329929

Fair Isaac Company (2015). Available online at: http://www.myfico.com/CreditEducation/articles/

Grablowsky, B.J., \& Talley, W.K. (1981). Probit and discriminant functions for classifying credit applicants: A comparison. Journal of Economic and Business, 33(3), 254-261.

Gutiérrez, M.A. (2008). Anatomía de losmodelos de credit scoring. Ensayos Económicos BCRA, 50, 61-96.

Hand, D.J., \& Jacka, S.D. (1998). Statistics in Finance. London: Arnold.

Hsieh, N., \& Hung, L. (2010). A data driven ensemble classifier for credit scoring analysis. Expert Systems with Applications, 37, 534-545. https://doi.org/10.1016/j.eswa.2009.05.059

Hu, Y., \& Ansell, J. (2007). Measuring retail company performance using credit scoring techniques. European Journal of Operational Research, 183, 1595-1606. https://doi.org/10.1016/j.ejor.2006.09.101

Jacobson, T., \& Roszbach, K. (2003). Bank lending policy, credit scoring and value-at-risk. Journal of Banking and Finance, 27, 615-633. https://doi.org/10.1016/S0378-4266(01)00254-0 
Kim, Y.S., \& Sohn, S.Y. (2004). Managing loan customers using misclassification patterns of credit scoring model. Expert Systems with Applications, 26, 567-573. https://doi.org/10.1016/j.eswa.2003.10.013

Marín, S., Antón, M., \& Mondragón, Z. (2011). Crisis bancarias, información financiera y modelos de predicción: Estudio de un caso. GCG: Revista de Globalización, Competitividad y Gobernabilidad, 5, 32-41.

Marshall, A., Tang, L., \& Milne, A. (2010). Variable reduction, simple selection bias and bank retail credit scoring. Journal of Empirical Finance, 17, 501-512. https://doi.org/10.1016/j.jempfin.2009.12.003

Ochoa, J.C., Galeano, W., \& Agudelo, L.G. (2010). Construcción de un modelo de scoring para el otorgamiento de crédito en una entidad financiera. Perfil de Coyuntura Económica, 16, 191-222.

Paleologo, G., Elisseeff, A., \& Antonini, G. (2010). Subagging for credit scoring models. European Journal of Operational Research, 201, 490-499. https://doi.org/10.1016/j.ejor.2009.03.008

Rayo, S., Lara, J., \& Camino, D. (2010). Un Modelo de Credit Scoring para instituciones de microfinanzas en el marco de Basilea II. Journal of Economics, Finance and Administrative Science, 28(15), 91-124.

Saladrigues, R., \& Grañó, M. (2014). Audit Expectation Gap: Fraud detection and other factors. European Accounting and Management Review, 2, 120-142.

Schreiner, M. (2002). Ventajas y desventajas del scoring estadístico para las microfinanzas. Microfinance Risk Management, Washington University in St. Louis, 1-40.

Schreiner, M. (2004). Scoring arrears at a Microlender in Bolivia. Journal of Microfinance, 6(2), 65-88.

Shu-Ting, L., Cheng, B., \& Hsieh, C. (2009). Prediction model building with clustering-launched classification and support vector machines in credit scoring. Expert Systems with Applications, 36, 7562-7566. https://doi.org/10.1016/j.eswa.2008.09.028

Tascón, M., \& Castaño, F. (2012). Variables y modelos para la identificación y predicción del fracaso empresarial: Revisión de la investigación empírica reciente. Revista de Contabilidad, 15(1), 7-58. https://doi.org/10.1016/S1138-4891(12)70037-7

Thomas, L.C. (2000). A survey of credit and behavioural scoring: Forecasting financial risk of lending to consumers. International Journal of Forecasting, 16, 149-172. https://doi.org/10.1016/S0169-2070(00)000340

Van Gool, J., Verbeke, W., Sercu, P., \& Baesens, B. (2012). Credit scoring for microfinance: Is it worth it?. International Journal of Finance and Economics, 17, 103-123. https://doi.org/10.1002/ijfe.444 
Viganó, L. (1993). A credit scoring model for development banks: An African case study. Savings and Development, 4, 441-482.

Wall, A. (1928). Ratio method and statement analysis. Nueva York: Harper.

Wang, G., Hao, J., Ma, J., \& Jiang, H. (2011). A comparative assessment of ensemble learning for credit scoring. Expert System with Applications, 38, 223-230. https://doi.org/10.1016/j.eswa.2010.06.048

Wang, G., Ma, J., Huang, L., \& Xu, K. (2012). Two credit scoring models based on dual strategy ensemble trees. Knowledge-Based Systems, 26, 61-68. https://doi.org/10.1016/j.knosys.2011.06.020

Zhou, X., Zhang, D., \& Jiang, Y. (2008). A New Credit Scoring Method Based on Rough Sets and Decision Tree. Advances in Knowledge Discovery and Data Mining, 5012, 1081-1089. https://doi.org/10.1007/978-3-540-68125-0_117

Zhou, L., Lai, K., \& Yen, J. (2009). Credit scoring models with AUC maximization based on weighted SVM. International Journal of Information and Decision Making, 8(4), 677-696.

https://doi.org/10.1142/S0219622009003582

Intangible Capital, 2017 (www.intangiblecapital.org)

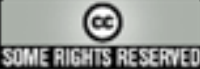

Article's contents are provided on an Attribution-Non Commercial 3.0 Creative commons license. Readers are allowed to copy, distribute and communicate article's contents, provided the author's and Intangible Capital's names are included. It must not be used for commercial purposes. To see the complete license contents, please visit http://creativecommons.org/licenses/by-nc/3.0/. 